\title{
PELAKSANAAN DISIPLIN DAN MOTIVASI KERJA KARYAWAN PADA SMK PENERBANGAN BANJARBARU
}

\author{
Widarto \\ E-mail: widarto@stiabinabanuabjm.ac.id
}

Feronika Lata Manjari

STIA BINA BANUA Banjarmasin

\begin{abstract}
The purpose of this study is to determine the implementation of discipline and work motivation of employees, to determine the factors that hinder the implementation of discipline and work motivation of the employees of Vocational High School Banjarbaru.

The method used is descriptive. Data collection techniques are observations, interviews and documentation. Data analysis techniques use qualitative analysis.

The results showed that the implementation of discipline and motivation was carried out starting from discipline on working hours and teaching schedules, motivating teachers and education personnel with incentives, conducting surveillance internally and externally, implementing sanctions in the form of incentive cuts. For the implementation of motivation, it is carried out by providing a salary according to the minimum wage, giving bonuses in the form of food allowance, overtime pay and other incentives, adequate work facilities, career paths, awards in the form of praise. The constraints faced in implementing discipline and motivation are the limited number of teachers and education personnel, the quality is not optimal, the coordination of educators and education personnel needs to be improved and the work discipline is not maximal. Whereas alternative solutions to overcome the constraint factor are increasing the number of permanent teachers through appointment or through requests for assistance from Dpk PNS Teachers or collaborating with other Public or Private Vocational Schools that have the same curriculum, improving the quality of employees through Education and Training conducted by the Government and Programmed Education and Training. itself, building intensive communication through various media and creating or refining job indicators to facilitate monitoring and evaluation.
\end{abstract}

Keywords : Discipline and Motivation 


\section{PENDAHULUAN}

Di era Revolusi Industri 4.0 dewasa ini menuntut adanya disiplin dan motivasi khususnya pada lembaga-lembaga pendidikan baik negeri maupun swasta. Disiplin tersebut salah satunya terkait dengan pelaksanaan proses belajar mengajar maupun dalam proses pelayanan yang berbasis teknologi informasi, banyak aktivitas yang harus berubah dari proses secara manual, komputerisasi menjadi sarana pelayanan menggunakan digitalisasi menggunakan internet atau sering disebut dengan daring atau dalam jaringan.

Begitu pula dengan SMK Penerbangan Banjarbaru dibawah naungan Yayasan Wiyata Borneo memiliki dua program studi keahlian yaitu (1) TEKNOLOGI DAN REKAYASA Keahlian Air Frame dan Power Plant (2) BISNIS DAN MANAJEMEN Keahlian Otomatisas dan Tata Kelola Perkantoran Konsentrasi Kebandarudaraan. Walaupun terbilang baru, SMK Penerbangan Banjarbaru sudah banyak dikenal oleh masyarakat.

Sebagai sekolah swasta tentu harus mempunyai rencana dan startegi yang tepat agar dapat bersaing dengan sekolah negeri maupun sekolah swasta lain yang ada di Kalimantan Selatan maupun kota-kota lainnya. Untuk menarik minat dan meyakinkan siswa-siswi lulusan Sekolah Menengah Pertama untuk memilih masuk ke SMK Penerbangan Banjarbaru, maka harus lebih dulu memberikan keyakinan kepada para siswa dan alumni bahwa kualitas SMK Penerbangan memang bisa dibanggakan, oleh karena itu untuk memberikan kepuasan kepada siswa-siswi harus selalu ditingkatkan melalui kualitas pelayanan dan proses pembelajaran yang dilakukan oleh tenaga pendidikan maupun tenaga guru. Untuk meningkatkan hal tersebut salah satunya melalui peningkatan disiplin dan motivasi kerja karyawan sehingga akan tercipta kepuasan pelayanan maupun kepuasan proses belajar mengajar menuju Kualitas Lulusan sesuai dengan harapan, bila itu terjadi maka sebagai SMK Penerbangan satu-satunya akan memiliki keunggulan tersendiri.

Berdasarkan observasi di SMK Penerbangan Banjarbaru, ada beberapa karyawan di SMK Penerbangan banjarbaru yang masih kurang disiplin yaitu, disiplin hadir. Peraturan jam masuk kerja di SMK Penerbangan Banjarbaru dari jam 07.25 s/d 16.30 WITA. Namun fakta nya masih ada beberapa karyawan yang datang melebihi jam 
Volume 7 Nomor 1, April 2021

masuk kerja yang sudah ditentukan, sehingga berdampak pada kinerja pendidik dan tenaga kependidikan yang kurang maksimal.

Kemajuan dan keberhasilan sekolah sangat tergantung pada kinerja karyawan dalam hal ini sebagai guru dan tenaga kependidikan dimana karyawan tersebut mampu bekerja keras, produktif, loyal serta disiplin tinggi, memiliki motivasi yang besar dan bertanggung jawab terhadap tugas dan pekerjaan yang pada akhirnya dapat mencapai kinerja yang optimal, sehingga berdampak positif pada sekolah.

Penelitian ini bertujuan untuk mengetahui disiplin dan motivasi kerja serta untuk untuk mengetahui faktor - faktor yang menghambat pelaksanaan disiplin dan motivasi kerja karyawan SMK Penerbangan Banjarbaru.

\section{TINJAUAN PUSTAKA}

Disiplin Menurut Lijan Poltak Sinambela (2019:334), disiplin adalah kepatuhan pada aturan atau perintah ditetapkan oleh organisasi. Disiplin adalah sebuah proses yang digunakan untuk menghadapi permasalahan kinerja; proses ini melibatkan manajer dalam mengidentifikasikan, mengomunikasikan dan menerapkan konsekuensinya sedangkan Edy Sutrisno (2017:87) mengemukakan disiplin sebagai sikap hormat terhadap peraturan dan ketetapan perusahaan, yang ada di dalam diri karyawan, yang menyebabkan iya dapat menyesuaikan diri dengan sukarela pada peraturan dan ketetapan perusahaan.

Dari pengertian tersebut dapat disimpulkan bahwa disiplin adalah perilaku karyawan yang dengan kesediaan dan kerelaan mematuhi peraturan yang dibuat oleh perusahaan untuk meningkatkan kinerja dan kualitas diri karyawan dalam bekerja.

Tidak kurang pentingnya untuk memperhatikan bahwa manajemen harus mampu menerapkan berbagai ketentuan yang berlaku secara efektif agar berbagai tujuan pendisiplinan seperti telah disinggung diatas tercapai, pendisiplinan harus diterapkan secara bertahap.Yang dimaksud dengan secara bertahap adalah dengan mengambil berbagai langkah yang bersifat pendisiplinan, mulai dari yang ringan hingga kepada yang bersifat berat. Misalnya dengan :

1. Peringatan lisan oleh penyelia/supervisor.

2. Pernyataan tertulis ketidakpuasan oleh atasan langsung.

3. Penundaan kenaikan gaji berkala.

4. Penundaan kenaikan jabatan. 
Volume 7 Nomor 1, April 2021

5. Pembebasan dari jabatan.

6. Pemberhentian semantara.

7. Pemberhentian atas permintaan sendiri.

8. Pemberhentian dengan hormat tidak atas permintaan sendiri.

9. Pemberhentian tidak dengan hormat (Siagian, $2012: 211$ ).

\section{Unsur-Unsur Yang Mempengaruhi Disiplin}

Menurut Anoraga (2011 : 46) yang dimaksud dengan unsur-unsur yang mempengaruhi disiplin adalah :

1. Adanya tata tertib atau peraturan serta penjabaran tugas dan wewenang

2. Tata kerja yang sederhana.

Dari faktor-faktor diatas, sedang keteladan dan ketaatan pengaturan merupakan penyerta dan penguat terhadap faktor utama tersebut. Teladan dan ketaatan pengaturan tidak akan mampu bertahan tanpa dilandasi oleh kesadaran. Sebaiknya jika masih ada kesadaran, maka keteladanan dan ketaatan pengaturan akan memperkuat sikap disiplin seseorang. Faktor keteladanan mendahului faktor ketaatan pengaturan tanpa ada keteladan, jelas hal itu pun tidak akan bertahan terhadap waktu.

Selanjutnya Veithzal Rivai (2005) dalam Lijan Poltak Sinambela 2019:355), yang menjelaskan bahwa disiplin kerja memiliki beberapa komponen, yaitu : Kehadiran, Ketaatan pada peraturan kerja, Ketaatan pada standar kerja, Tingkat kewaspadaan tinggi, dan Bekerja etis.

Sedangkan menurut H. Edy Sutrisno (2017:93), faktor yang mempengaruhi disiplin kerja karyawan, yaitu :

1. Kepemimpinan.

2. Keadaan karyawan itu sendiri.

3. Peraturan-peraturan yang diberlakukan dalam organisasi.

Menurut Bejo Siswanto (2005) di dalam Lijan Poltak Sinambela 2019:340), menguraikan bahwa maksud dan sasaran dari disiplin kerja adalah terpenuhinya beberapa tujuan seperti:

1. Tujuan umum disiplin kerja. Tujuan umum disiplin kerja adalah demi kelangsungan perusahaan sesuai dengan motif organisasi bagi yang bersangkutan baik hari ini, maupun hari esok. 
2. Tujuan khusus disiplin kerja.Tujuan khusus antara lain:

a. Untuk para pegawai menepati segala peraturan dan kebijakan keternagakerjaan maupun peraturan, serta kebijakan perusahaan yang berlaku, baik yang tertulis, serta melaksanakan perintah manajemen;

b. Dapat melaksanakan pekerjaan sebaik-baiknya, serta mampu memberikan servis yang maksimal pada pihak tertentu yang berkepentingan dengan perusahaan sesuai dengan bidang pekerjaan yang diberikan kepadanya;

c. Dapat menggunakan dan memelihara sarana dan prasarana barang dan jasa perusahaan dengan sebaik-baiknya;

d. Dapat bertindak dan berperilaku sesuai dengan norma-norma yang berlaku pada perusahaan;

e. Tenaga kerja mampu memperoleh tingkat produktivitas yang tinggi sesuai dengan harapan perusahaan, baik dalam jangka pendek maupun jangka panjang.

Motivasi Menurut H. Edy Sutrisno (2017), motivasi memiliki komponen, yakni komponen dalam dan luar. Komponen dalam ialah perubahan dalam diri seseorang, keadaan merasa tidak puas, ketegangan psikologi. Komponen luar ialah apa yang diinginkan seseorang, tujuan yang menjadi arah tingkah lakunya.

Adapun ciri sistem kerjasama tersebut antara lain :

1. Ada komunikasi antara orang yang bekerjasama.

2. Individu dalam organsiasi tersebut mempunyai kemampuan untuk kerjasama.

3. Kerjasama itu ditujukan untuk mencapai tujuan (Reksohadiprodjo dan Handoko, 2010).

Pada umumnya bentuk motivasi yang dianut perusahaan meliputi 4 unsur utama :

1. Kompensasi yang berbentuk uang, pemberian kompensasi bentuk uang sebagai motivasi kerja mempunyai 2 hal pengaruh yang positif dalam arti yang menguntungkan bagi perusahaan dan mempunyai tenaga kerja pada semua tingkatan pendapatan.

2. Pengarahan dan pengendalian, dimaksudkan untuk menentukan bagi pekerja tentang apa yang harus dikerjakan sesuai instruksi. Hal ini digunakan oleh para pimpinan untuk memotivasi para tenaga kerja.

3. Penetapan pola kerja yang efektif. 
Volume 7 Nomor 1, April 2021

4. Kebijakan merupakan suatu tindakan manajer untuk mempengaruhi perasaan para tenaga kerja untuk membuat tenaga kerja bahagia (Cahyono, 2017; Widyanti R., 2021)

Selanjutnya menurut Davis dan werther dikutip marwansyah 2016 didalam Widarto dan Alexander Wilar, 2017 mengelompokkan kompensasi kedalam dua bentuk yang umum yaitu Kompensasi Langsung dan kompensasi tidak langsung. Jadi motif motivasi kerja adalah sesuatu yang menimbulkan semangat atau dorongan kerja.Oleh sebab itu, motivasi kerja dalam psikologi karya biasa disebut pendorong semangat kerja.Kuat lemahnya motivasi kerja seorang tenaga kerja ikut menentukan besar kecilnya prestasinya. Kebutuhan-kebutuhan manusia menurut Anoraga (2011 :39) dapat dibagi menjadi dua golongan :

1. Kebutuhan primer, yang pada umumnya merupakan kebutuhan vital, seperti lapar, haus, seks, tidur, suhu yang menyenangkan dan lain sebagainya. Semua ini adalah kebutuhan-kebutuhan hidup seseorang. Kebutuhan-kebutuhan semacam ini timbul dengan sendirinya atau sudah ada sejak seseorang lahir sehingga disebut kebutuhan primer.

2. Kebutuhan sekunder, yang timbul dari interaksi antara orang dengan lingkungannya seperti kebutuhan untuk bersaing, bergaul, bercinta, ekspresi diri, harga diri dan sebagainya. Kebutuhan sekunder inilah yang paling banyak berperan dalam motivasi seseorang.

Abraham Maslow (1970 di dalam Emron Edison, Yohny Anwar, Imas Komariyah, 2018:173) menunjukan bahwa manusia memiliki kebutuhan dan sifat yang berfungsi sebagai penggerak perilaku. ada lima jenjang kebutuhan yang tersusun dalam suatu hierarki, yaitu:

1. Pysiological needs

2. Safety needs atau security needs

3. Affection needs atau love needs atau belonging needs

4. Esteem needs

5. Self-actualization needs 
Volume 7 Nomor 1, April 2021

\section{METODE PENELITIAN}

Penelitian ini menggunakan metode deskriptif dengan teknik pengumpulan data adalah wawancara, Observasi dan Dokumentasi. Teknik analisa data yang digunakan adalah analisa kualitatif

\section{HASIL DAN PEMBAHASAN}

Pelaksanaan Disiplin

Pelaksanaan disiplin kerja SMK Penerbangan Banjarbaru dilakukan untuk menjamin bahwa pelaksanaan program dan proses pembelajaran dapat berjalan sesuai dengan yang direncanakan. Pelaksanaan tersebut meliputi :

1. Membuat Aturan Jam Kerja

Bagi Tenaga Pendidik dan tenaga kependidikan yang statusnya Guru atau Karyawan Tetap diharuskan hadir sesuai dengan peraturan yang dibuat oleh SMK penerbangan, sedangkan untuk guru tidak tetap atau honor dibuatkan jadwal tersendiri untuk hadir, terutama Jadwal Mengajar. Untuk menjamin tidak tumpang tindih dan menghindari kelas kosong, maka tenaga honor lebih diprioritaskan untuk memilih jadwal sesuai dengan yang diinginkan, namun masih mengacu pada orientasi kelancaran dan kualitas proses belajar mengajar.

2. Memotivasi Pendidik dan Tenaga Kependidikan dengan Insentif.

Semangat kerja pendidik dan tenaga kependidikan dalam melaksanakan aktivitas kerja dipengaruhi oleh beberapa faktor, antara lain rasa memiliki terhadap pekerjaan, dan besarnya insentif yang diberikan. Apabila hal tersebut tidak dipenuhi, maka sebagian besar pendidik dan tenaga kependidikanakan kurang termotivasi dan kurang memiliki rasa bertanggung jawab terhadap pekerjaan yang diberikan.

Berdasarkan wawancara dengan ibu Henny Arianty, SEselaku bagian administrasi dan sumber daya manusia pada SMK Penerbangan Banjarbaru, dalam pemberian insentif material yang berupa gaji dan bonus, dirasakan pendidik dan tenaga kependidikan sudah cukup baik. Untuk mencapai tingkat yang lebih, pimpinan memotivasi pendidik dan tenaga kependidikannya dengan pemberian insentif nonmaterial yang berupa pujian, keadilan, dan perlakuan yang wajar.Untuk dapat meningkatkan disiplin kerja pendidik dan tenaga kependidikan dilakukan melalui beberapa tahap yaitu Disiplin diri sendiri, Disiplin lingkungan, dan Disiplin kerja. 
a. Setiap organisasi ingin memberikan sesuatu yang terbaik bagi pendidik dan tenaga kependidikan, dan penerapan disiplin itu merupakan salah satu usaha untuk memotivasi pendidik dan tenaga kependidikan agar dapat menghargai waktu dan mempunyai tanggung jawab terhadap pekerjaan yang telah diberikan.

b. Menerapkan Sistem Penghargaan

Guna memacu produktivitas pendidik dan tenaga kependidikan, Lembaga pendidikan memberlakukan sistem penghargaan tertentu, dimana pendidik dan tenaga kependidikan yang disiplin, rajin, berprestasi dalam bekerja akan mendapat penghargaan sebagai karyawan teladan. Penghargaan berupa piagam penghargaan dan hadiah bisa berupa uang ataupun barang.Pendidik dan tenaga kependidikan yang berprestasi, dengan sendirinya akan membentuk karakter yang baik karena adanya keinginan untuk berkembang dan merasa mempunyai tanggung jawab terhadap pekerjaan, sehingga tidak perlu diawasi dengan ketat dalam bekerja. Faktor intrinsik motivasi, dimana keinginan dan kepuasan timbul dari diri sendiri.

2. Melakukan Pengawasan secara Internal maupun Eksternal

Untuk lebih mengetahui prestasi kerja pendidik dan tenaga kependidikan, pimpinan mengadakan pengawasan terhadap kinerja pendidik dan tenaga kependidikan secara berkala. Berdasarkan wawancara dengan ibu Henny Arianty, SE selaku bagian administrasi dan sumber daya manusia pada SMK Penerbangan Banjarbaru, sistem pengawasan yang digunakan adalah sebagai berikut :

a. PengawasanInternal.

Pengawasan dari dalam lingkungan sekolah, yang dilakukan langsung oleh kepala sekolah terhadap pendidik dan tenaga kependidikan mengenai pekerjaan dan kebijakan yang telah ditetapkan serta pengawasan terhadap pelayanan administrasi dan pembelajaran.Pengawasan dilakukan berkala setiap hari atau satu minggu sekali, dengan harapan pendidik dan tenaga kependidikanakan merasa bertanggung jawab terhadap pekerjaan yang telah diberikan dan hasil pelayanan administrasi dan pembelajaran yang memuaskan.

b. Pengawasan Eksternal.

Pengawasan yang dilakukan dari masyarakat kepada pendidik dan tenaga kependidikan mengenai apa saja kegiatan yang dilakukan SMK Penerbangan 
Banjarbaru. Misalnya, seorang pendidik dan tenaga kependidikan yang menyalahgunakan wewenang yang diberikan di luar lembaga pendidikan untuk hal-hal yang tidak baik maka masyarakat bisa menilai bahwa pendidik dan tenaga kependidikan itu perlu untuk dilaporkan ke pihak lembaga pendidikan.

3. Menciptakan Situasi dan Iklim yang Kondusif bagi Pendidik dan tenaga kependidikan.

Guna mempertahankan dan meningkatkan disiplin SMK Penerbangan Banjarbaru berusaha menciptakan situasi dan iklim yang kondusif bagi seluruh pendidik dan tenaga kependidikan dalam bekerja.Untuk menciptakan situasi tersebut, SMK Penerbangan Banjarbaru menyediakan fasilitas-fasilitas kerja yang memadai dan memenuhi syarat, melindungi pendidik dan tenaga kependidikan dalam program asuransi, sehingga pendidik dan tenaga kependidikan dapat berinovasi dan berkreasi dalam rangka mengaktualisasikan diri. Keamanan, kenyamanan, dan kebersihan tempat kerja juga merupakan prioritas yang diutamakan oleh lembaga pendidikan untuk meningkatkan semangat kerja pendidik dan tenaga kependidikan, sehingga memiliki disiplin yang tinggi.

4. Memberikan Sanksi berupa Pemotongan Insentif.

SMK Penerbangan Banjarbaru dalam memberikan insentif bagi pendidik dan tenaga kependidikan sudah cukup adil, yaitu pada bagian-bagian atau unit-unit tertentu diberikan insentif karena pertimbangan tanggung jawab dan resiko tertentu, dimana bagian-bagian tersebut memiliki resiko dan tanggung jawab yang sangat besar terhadap perkembangan sekolah.

Selain itu SMK Penerbangan Banjarbaru juga memberikan kebijakan berupa uang makan kepada seluruh pendidik dan tenaga kependidikan yang bekerja lembur seperti ada kegiatan yang berada diluar lingkungan sekolah dan memakan waktu yang cukup lama bahkan bisa sampai berhari-hari salah satunya seperti kegiatan promosi. Hal ini dilakukan guna memberikan insentif lebih kepada pendidik dan tenaga kependidikan, bukan hanya sekedar memenuhi ketentuan yang ditetapkan lembaga pendidikan, akan tetapi guna memberikan dorongan agar timbul semangat kerja yang bisa miningkatkan produktivitas kerja pendidik dan tenaga kependidikan, tetapi bagi yang tidak melakukan disiplin sesuai yang ditugaskan maka akan mendapat sangsi bahwa insentif akan dipotong, bahkan tidak diberikan kepada karyawan. 
Volume 7 Nomor 1, April 2021

\section{Pelaksanaan Motivasi}

Cara yang dilakukan SMK Penerbangan Banjarbaru dalam memotivasi Pendidik dan tenaga kependidikannya yaitu dengan jenis motivasi material dan motivasi nonmaterial secara positif maupun negatif, berupa :

\section{Gaji Pokok sesuai dengan UMR}

Gaji merupakan bentuk imbalan yang harus diterima pendidik dan tenaga kependidikan karena sudah melakukan pekerjaan.Dalam memenuhi kebutuhan, seorang pendidik dan tenaga kependidikan membutuhkan gaji dalam bekerja.Gaji diberikan sesuai dengan bentuk pekerjaan baik harian, mingguan, maupun bulanan.Gaji merupakan hal pokok yang harus diberikan SMK Penerbangan Banjarbaru kepada pendidik dan tenaga kependidikan sebagai bentuk imbalan jasa yang ditujukan untuk meningkatkan semangat kerja kayawan dalam bekerja. Standar gaji yang digunakan SMK Penerbangan Banjarbaru sudah sesuai dengan standar Upah Minimum Regional (UMR) Kota Banjarbaru yaitu sebesar Rp 2.769.550,- per bulannya.

\section{Bonus}

SMK Penerbangan Banjarbaru menggunakan bonus untuk meningkatkan kinerja pendidik dan tenaga kependidikan, dengan adanya bonus yang diberikan maka pendidik dan tenaga kependidikanakan termotivasi untuk menunjukkan kemampuan yang dimiliki dalam bekerja.Bonus diberikan sebagai tambahan uang yang diberikan kepada pendidik dan tenaga kependidikan karena prestasi.Tenaga pendidik dan tenaga kependidikan yang teladan memperoleh penghargaan dari pihak sekolah berupa bonus atapun hadiah lainnya. Untuk pendidik dan tenaga kependidikan yang berprestasi, bekerja lembur atau dinas luar kota mendapatkan bonus seperti uang saku dan uang makan.

\section{Fasilitas Kerja}

Dalam menjalankan pekerjaan, pendidik dan tenaga kependidikan membutuhkan fasilitas kerja yang memadai untuk mendukung kelancaran pelaksanaan pekerjaan.Fasilitas kerja juga sangat mempengaruhi kinerja pendidik dan tenaga kependidikan, karena fasilitas merupakan kebutuhan tambahan yang dapat dirasakan pendidik dan tenaga kependidikan dilingkungan lembaga pendidikan.SMK Penerbangan Banjarbarumemberikan fasilitas kerja dalam 
bentuk peralatan dan perlengkapan kerja.Peralatan kerja yang diberikan SMK Penerbangan Banjarbaru kepada pendidik dan tenaga kependidikannya adalah berupa fasilitas ruangan yang baik.

\section{Jenjang Karier atau Penempatan Jabatan.}

Penempatan jabatan yang diberikan harus sesuai dengan bidang dan kemampuan masing-masing pendidik dan tenaga kependidikan, dengan penempatan jabatan yang sesuai membuat pekerjaan akan mudah terselesaikan dengan baik. SMK Penerbangan Banjarbaru, dalam menempatkan jabatan sesuai dengan pendidikan pendidik dan tenaga kependidikan.

5. Pujian dan Penghargaan

Selalu dianggap terbaik dalam bekerja adalah suatu hal yang di inginkan pendidik dan tenaga kependidikan untuk menunjukkan keseriusan dalam bekerja.Untuk itu, pimpinan SMK Penerbangan Banjarbaru perlu memberikan pujian terhadap para pendidik dan tenaga kependidikannya jika pekerjaan yang dilakukan sangat baik (sempurna). Dengan pujian yang diberikan pimpinan, pendidik dan tenaga kependidikanakan merasa puas dan akan termotivasi untuk meningkatkan kinerjanya. Selain iyu secara periodik, lembaga pendidikan menunjuk pendidik dan tenaga kependidikan terbaik/teladan dalam setiap bidang pelayanan administrasi dan pembelajaran, untuk diberi penghargaan (piagam, uang, dll).Dalam hal ini, pendidik dan tenaga kependidikan memiliki motivasi tinggi dengan melakukan sesuatu dengan sebaik-baiknya dan memiliki tingkat tanggung jawab pribadi yang tinggi terhadap pekerjaan.Beberapa orang mempunyai dorongan yang kuat untuk mencapai hasil yang baik, jadi penghargaan diberikan sebagai bentuk kepedulian lembaga pendidikan terhadap kebutuhan pendidik dan tenaga kependidikan sesuai dengan prestasi yang dimilikinya.

Kendala atau factor penghambat Pelaksanaan Disiplin dan Motivasi Kerja dan Alternative Solusinya, yaitu :

\section{Jumlah tenaga guru tetap terbatas}

Adanya keterbatasan guru tetap yang terdapat di SMK Penerbangan Banjarbaru menyebabkan terjadinya pemberian materi pelajaran ganda sehingga parapendidik dan tenaga kependidikan mengalami banyak kegiatan untuk melaksanakan tugas yang diemban dan tambahan tersebut merupakan bagian dari pekerjaan yang harus dilaksanakan bagi pendidik dan tenaga kependidikan. 
Volume 7 Nomor 1, April 2021

Adapun setiap pendidik dan tenaga kependidikan memiliki karakter yang tidak sama, sehingga keinginan pendidik dan tenaga kependidikan yang satu dengan yang lain tidak sama. Alat motivasi yang digunakan SMK Penerbangan Banjarbaru sudah cukup efektif, tapi pendidik dan tenaga kependidikan belum tentu puas dengan sistem motivasi yang digunakan lembaga pendidikan. Jumlah guru Tetap ada 16 Orang, Tenaga Kependidikan 4 Orang dan Guru Honorer atau kontrak ada 8 Orang

2. Kualitas pendidik dan tenaga kependidikan yang belum optimal

Kualitas pendidik dan tenaga kependidikan yang ada di SMK penerbangan Banjarbaru masih belum optimal, hal tersebut mengingat untuk menjadi tenaga pendidik atau guru dituntut adanya syarat pendidikan yang linear dengan bidang pelajaran yang akan disampaikan. Selain itu masih banyak tenaga honor yang secara formal kurang memiliki ikatan yang kuat dengan lembaga SMK Penerbangan, sehingga untuk meningkatkan kompetensinya masih tergantung pada kesadaran dari para guru itu sendiri dan SMK penerbangan belum memiliki kewenangan untuk memaksa pada guru yang bersangkutan, padahal dengan adanya perubahan teknologi yang massif sekarang ini yaitu era revolusi industry 4.0 tentu saja tuntutan kompetensi guru di SMK penerbangan harus terus ditingkatkan.

3. Koordinasi pendidik dan tenaga kependidikan perlu ditingkatkan

Pendidik dan tenaga kependidikan di SMK Penerbangan Banjabaru tidak semuanya adalah guru tetap, ada beberapa guru tidak tetap yang mengajar hanya pada waktu tertentu. Koordinasi disini dimaksudkan adalah pengaturan waktu belajar-mengajar guru tidak tetap yang, sering terjadi perubahan jadwal dikarenakan pada saat jam pelajaran ada guru yang tidak masuk pada jam yang ditetapkan, hal tersebut kemungkinan guru tidak tetap tersebut juga mengajar ditempat lain, sedangkan kompetensi guru tidak tetap tersebut memiliki kompetensi yang sangat baik, sehingga mau tidak mau penjadwalan ulang harus dilakukan dan guru tetap yang harus mengalah.

4. Disiplin Kerja Belum Optimal

Dalam hal disiplin sudah berjalan sesuai dengan yang diharapkan, tetapi kadang kala masih ditemui pendidik dan tenaga kependidikan pada saat jam masuk kerja yang terlambat. Selain itu kalaupun datang tepat waktu masih ada yang kurang 
Volume 7 Nomor 1, April 2021

serius dalam menjalankan tugasnya yaitu terlihat ada pendidik dan tenaga kependidikan yang banyak bercanda dengan rekan kerjanya selama jam kerja berlangsung.

Untuk mengatasi faktor-faktor penghambat atau kendala ada beberapa alternative solusi yang selama ini dilakukan dan perlu dimaksimalkan yaitu :

1. Penambahan jumlah tenaga guru tetap

Memang kalau persoalan secara jumlah kurang, langkah yang harus diambil adalah menambah jumlah tenaga guru tetap, akan tetapi penambahan tersebut harus disesuaikan dengan kemampuan SMK penerbangan. Bila penambahan memungkinkan maka perlu ditambah, akan tetapi jika belum memungkinkan penambahan tersebut dapat dilakukan dengan pendekatan ke Dinas Provinsi Kalimantan Selatan untuk memohon bantuan tenaga guru dari PNS Dpk, karena keberadaan SMK penerbangan sangat membantu Daerah guna menciptakan lapangan kerja dibidang Penerbangan, apalagi merupakan satu-satunya di Kalimantan Selatan. Selain itu perlu diupayakan kerjasama dengan SMK baik Negeri maupun swasta yang memiliki kurikulum yang sama.

2. Peningkatan kualitas pendidik dan tenaga kependidikan

Salah satu cara yang dilakukan pihak lembaga SMK Penerbangan Banjarbaru adalah dengan cara melaksanakan pendidikan dan pelatihan bagi pendidik dan tenaga kependidikan secara berkesinambungan dan berkelanjutan dengan bekerjasama dengan pihak Dinas Pendidikan maupun sesuai dengan jurusan dan konsentrasi bidang pembelajaran yang ada di SMK Penerbangan Banjarbaru. Untuk meningkatkan kualitas selama ini yang dilakukan adalah mengikut sertakan guru dalam kegiatan Diklat baik yang diadakan oleh pemerintah maupun Diklat yang dibiayai sendiri oleh SMK Penerbangan, namun pelaksanaannya masih banyak yang bersifat incidental hal tersebut perlu ditingkatkan lagi dimasa mendatang

3. Meningkatkan Komunikasi antara guru tetap dan guru tidak tetap Adanya kegiatan pembelajaran yang dijalankan para pendidik dan tenaga kependidikan merupakan tugas dan tanggung jawab bersama, maka untuk kelancaran pelaksanaannya perlu dibangun presepsi yang sama baik antara Guru Tetap dan Tidak Tetap, artinya koordinasi awal dilakukan dalam penetapan jadwal pelajaran, kemudian pada saat pelaksanaan atau implementasi perlu 
Volume 7 Nomor 1, April 2021

ditingkatkan komunikasi antar personal utamanya dilakukan oleh Kepala Sekolah, apabila guru tidak tetap berhalangan pada jam pelajaran dapat secara langsung diisi oleh materi pelajaran yang lain atau memajukan mata pelajaran yang lain dan guru tetap harus selalu berada ditempat untuk mengantisipasi hal tersebut, apalagi kalau pemberitahuannya satu hari sebelumnya tentu akan lebih mudah. Untuk kelancaran koordinasi tersebut dapat dibuat Group Komunikasi melalui media social (WathAp) akan lebih efisien dan tenaga kependidikan harus proaktif untuk menggali informasi dari para guru, sehingga informasi lebih cepat diperoleh dan ditindak lanjuti

4. Menoptimalkan disiplin

Agar lebih mudah dalam pelaksanaan disiplin, maka perlu dibuat aturan yang jelas terkait dengan tugas pokok dan fungsi baik tenaga pendidik maupun tenaga kependidikan, oleh karena itu perlu dibuat rancangan Indikator Pekerjaan yang akan dikerjakan oleh Tenaga kependidikan, misalnya Rancangan Satuan Acara Pembelajaran sesuai dengan kurikulum selalu update dan terus dievaluasi oleh pimpinan terutama kepala sekolah, sedangkan Untuk Tenaga kependidikan perlu dibuatkan Uraian dan deskripsi pekerjaan yang disesuaikan dengan tugas pokok dan fungsinya, sehingga apapun yang dilakukan oleh mereka sudah ada tolak ukurnya baik secara kuantitas maupun secara kualitas.

Simpulan

1. Pelaksanaan Disiplin dan motivasi kerja karyawan di SMK Penerbangan Banjarbaru Membuat Jadwal Jam Kerja dan Jadwal Mengajar, Memotivasi Pendidik dan Tenaga Kependidikan dengan Insentif, melakukan pengawan secara internal maupun eksternal, Sanksi berupa pemotongan insentif. Untuk pelaksanaan motivasi dengan pemberian Gaji yang sesuai UMR, Pemberian Bonus-Bonus berupa uang makan, uang lembur dan insentif lainnya, Fasilitas kerja yang memadai, Jenjang karir, Penghargaan dalam bentuk Pujian.

2. Kendala pelaksanaan disiplin dan motivasi yang dihadapi adalah jumlah Tenaga Pendidik dan Kependidikan Terbatas, Kualitas belum optimal, Koordinasi pendidik dan tenaga kependidikan perlu ditingkatkan dan disiplin kerja belum maksimal.

3. Alternatif solusi mengatasi faktor kendala adalah Penambahan jumlah tenaga guru tetap melalui pengangkatan atau melalui permohonan bantuan Tenaga Guru PNS Dpk atau 
Volume 7 Nomor 1, April 2021

menjalin kerjasama dengan SMK Negeri atau Swasta lain yang memiliki kurikulum yang sama, meningkatkan kualitas karyawan melalui Diklat.

\section{DAFTAR PUSTAKA}

Cahyono, Tri, Bambang. 2010. Manajemen Sumber Daya Manusia. ICWI Jakarta

Dessler, Garry. 2010. Manajemen Sumber Daya Manusia. Presshindo Jakarta

Edison Emron, Yojny Anwar, Imas Komariyyah, 2018. Manajemen Sumber Daya Manusia. Alfa Beta Bandung

Handoko, T, Hani .2011. Manajemen Personalia dan Sumber Daya Manusia. Badan Penerbit Fakultas Ekonomi Yogyakarta

Hasibuan S.P. Malayu, 2011. Manajemen Sumber Daya Manusia. PT. Alex Media Komputindo. Jakarta

Ishak, Arief. 2016. Pelatihan AMT untuk Meningkatkan Motivasi. www//repositori.unica. co.id.

Mangkunegara, Prabu, AA Anwar. 2012. Manajemen Sumber Daya Manusia Perusahaan. PT Remaja Rosdakarya Bandung

Mangkuprawira, Syafri. 2010 Manajemen Sumber Daya Manusia. Ghalia Indonesia Jakarta

Nasution S. 2012. Metode Penelitian Naturalistik-Kualitatif. Tarsito Bandung

Nawawi, Hadari. 2010. Manajemen Sumber Daya Manusia Perusahaan. Bina Aksara

Notoadmojo, Soekidjo. 2012. Pengembangan Sumber Daya Manusia : PT. Rineka Cipta Jakarta

Rachmawati, 2010. Manajemen Sumber Daya Manusia. Penerbit Erlangga Jakarta.

Sinambela Lijan Poltak, 2019. Manajemen Sumber Daya Manusia. PT Bumi Aksara Jakarta

Siagian, Sondang P. 2010. Manajemen Sumber Daya Manusia. Bina Aksara Jakarta

Sugiyono, 2010. Metode Penelitian Kuantitatif, Kualitatif dan RND. Alfa Beta Bandung

Sutrisno Edy, 2017. Manajemen Sumber Daya Manusia. Kencana Jakarta

Tulus, Agus. Moch. 2012. Manjemen Sumber Daya Manusia. Gramedia Indonesia Jakarta

Widarto, Wilar, Alexander 2017. Pelaksanaan Diklat dan Kompensasi Pada PT. Bumi Sumber Karya. Jurnal Administraus-Jurnal Ilmu Administrasi dan Manajemen Volume 3 No. 1-Januari 2019 E-ISSN 2580-9695

Widarto dan Muhammad Ary Saputra, 2019, Pelaksanaan Promosi Pada PT. Mitra Megah Profitamas Cabang Tanjung, AL-ULUM ILMU SOSIAL DAN HUMANIORA, ISSN: 2476 - 9576, Volume 5 Nomor 2, Oktober 2019.

Winardi J. 2012. Motivasi dan Pemotivasian. PT Raja Grafindo Persada Jakarta.

Widyanti, Rahmi, 2021, Perilaku Organisasi: Teori dan Konsep, Jilid 1, Penerbit Media Sains Indonesia Bandung, https://scholar.google.co.id/citations?user=ka0E86IAAAAJ 